\title{
High Throughput Analysis of Integron Gene Cassettes in Wastewater Environments
}

Joao Gatica, ${ }^{\dagger,}$ Vijay Tripathi, ${ }^{\ddagger}$ Stefan Green, ${ }^{\S}$ Celia M. Manaia, ${ }^{\prime \prime}$ Thomas Berendonk, ${ }^{\perp}$ Damiano Cacace, ${ }^{\perp}$ Christophe Merlin, ${ }^{\#, \nabla}$ Norbert Kreuzinger, ${ }^{\bigcirc}$ Thomas Schwartz, ${ }^{\triangleright}$ Despo Fatta-Kassinos, ${ }^{\text {IL }}$ Luigi Rizzo, ${ }^{\infty}$ Carsten U. Schwermer, ${ }^{\otimes}$ Hemda Garelick, ${ }^{\star}$ Edouard Jurkevitch, ${ }^{\varnothing}$ and Eddie Cytryn ${ }^{*},^{\dagger}$

${ }^{\dagger}$ The Institute of Soil, Water and Environmental Sciences, The Volcani Center, Agricultural Research Organization, Bet-Dagan, Israel

${ }^{\ddagger}$ The Department of Soil and Water Sciences, The Robert H. Smith Faculty of Agriculture, Food and Environment, The Hebrew University of Jerusalem, Rehovot, Israel

${ }^{\S}$ DNA Services Facility, Research Resources Center, University of Illinois at Chicago, Chicago, Illinois 60612, United States

"Escola Superior de Biotecnologia, Universidade Católica Portuguesa, Lisboa, Portugal

${ }^{\perp}$ Faculty of Environmental Sciences, Technische Universität Dresden, Dresden, Germany

${ }^{\#}$ CNRS, Laboratoire de Chimie Physique et Microbiologie pour l'Environnement (LCPME), UMR 7564, Institut Jean Barriol, 15 Avenue du Charmois, 54500 Vandoeuvre-lès-Nancy, France

${ }^{\nabla}$ Université de Lorraine, LCPME, UMR 7564, 15 Avenue du Charmois, 54500 Vandoeuvre-lès-Nancy, France

Onstitute for Water Quality, Resources and Waste Managment, Technische Universität Wien, Wien, Austria

Karlsruhe Institute of Technology, Eggenstein-Leopoldshafen, Germany

${ }^{\mathbb{I}}$ Department of Civil and Environmental Engineering and Nireas, International Water Research Center, University of Cyprus, P.O. Box 20537, 1678 Nicosia, Cyprus

${ }^{\infty}$ Department of Civil Engineering, University of Salerno, Salerno, Italy

${ }^{\otimes}$ Norwegian Institute for Water Research, Oslo, Norway

${ }^{M}$ School of Science and Technology, Middlesex University, London, U.K.

${ }^{\varnothing}$ The Department of Plant Pathology and Microbiology, The Robert H. Smith Faculty of Agriculture, Food and Environment, The Hebrew University of Jerusalem, Rehovot, Israel

\section{Supporting Information}

ABSTRACT: Integrons are extensively targeted as a proxy for anthropogenic impact in the environment. We developed a novel high-throughput amplicon sequencing pipeline that enables characterization of thousands of integron gene cassette-associated reads, and applied it to acquire a comprehensive overview of gene cassette composition in effluents from wastewater treatment facilities across Europe. Between 38100 and 172995 reads persample were generated and functionally characterized by screening against $\mathrm{nr}$, SEED, ARDB and $\beta$-lactamase databases. Over $75 \%$ of the reads were characterized as hypothetical, but thousands were associated with toxin-antitoxin systems, DNA repair, cell membrane function, detoxification and aminoglyco-

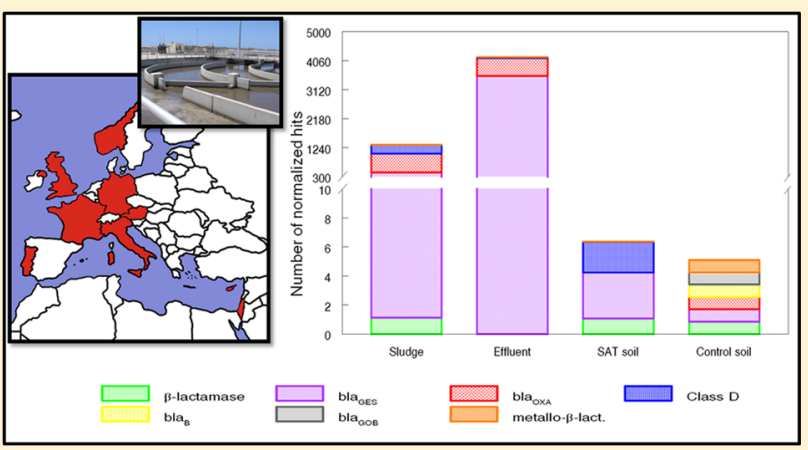
side and $\beta$-lactam resistance. Among the reads characterized as $\beta$ lactamases, the carbapenemase $b l a_{\mathrm{OXA}}$ was dominant in most of the effluents, except for Cyprus and Israel where $b l a_{\mathrm{GES}}$ was also abundant. Quantitative PCR assessment of $b l a_{\mathrm{OXA}}$ and $b l a_{\mathrm{GES}}$ genes in the European effluents revealed similar trends to those displayed in the integron amplicon sequencing pipeline described above, corroborating the robustness of this method and suggesting that these integron-associated genes may be excellent targets for source tracking of effluents in downstream environments. Further application of the above analyses revealed several order-of-magnitude reductions in effluent-associated $\beta$ lactamase genes in effluent-saturated soils, suggesting marginal persistence in the soil microbiome.

\section{INTRODUCTION}

The substantial increase in antibiotic resistance (AR) observed since the initial use of antibiotics in the 1940s, coupled to
Received: June 27, 2016

Revised: September 25, 2016

Accepted: September 30, 2016

Published: September 30, 2016 
projections of global AR propagation in the coming decades, ${ }^{1}$ has resulted in increasing interest in this phenomenon. In this context, wastewater treatment plants (WWTPs) are considered to be hotspots for the proliferation and dissemination of antibiotic resistant bacteria (ARB) and antibiotic resistance genes (ARGs). ${ }^{2-4}$

Dissemination and acquisition of ARGs in bacteria can be facilitated by mobile genetic elements (MGEs) and gene acquisition elements such as plasmids and integrons, respectively. ${ }^{5,6}$ In integrons, gene cassettes (GCs) can be integrated to bacterial chromosomes or plasmids through sitespecific recombination catalyzed by a tyrosine recombinase termed integrase. ${ }^{6,7}$ Although they are ubiquitous in the environment, ${ }^{8}$ their relative abundance is often correlated to local anthropogenic pressure. ${ }^{6,8-15}$ For example, a strong linkage between integron GCs and antibiotic and metal resistance genes ${ }^{6,12,16}$ has been observed in human impacted environments. ${ }^{17,18}$ Therefore, integrons and especially the class 1 integrase gene (intI1) have been targeted as a proxy for source tracking of anthropogenic impact in the environment. $^{\text {9,19,20 }}$

Several studies have monitored integrons in different WWTP compartments and in wastewater effluents. Integrase genes generally persist during wastewater treatment, ${ }^{21-24}$ and some studies have even found that the relative abundance of intI1 may actually increase in the course of conventional wastewater treatment processes. ${ }^{4,8,25-27}$ Mokracka et al. ${ }^{28}$ determined that several factors such as differences in wastewater characteristics, employed treatment processes, selective pressure imposed by antimicrobial drug use and geographical location affect the frequency of integrons; whereas Stalder et al. ${ }^{29}$ determined that although relative abundance of integrons was stable throughout the WWTP process, the diversity of gene cassette arrays in the effluent significantly decreased compared to the inflow, underlining the effect of the biological treatment on the anthropogenic integron pool.

Although integrase genes are increasingly used as a marker for anthropogenic impact, few studies have assessed actual GC content in integrons from wastewater effluents, and for the most part, these have targeted integrons from specific strains of cultured bacteria rather than from the entire wastewater microbiome. Collectively, results have shown that integron GCs are frequently dominated by genes conferring resistance to aminoglycosides, trimethoprim, $\beta$-lactams and erythromycin. $^{29-31}$

The regions flanking integron GCs are highly conserved and they therefore have been targeted to amplify GCs. ${ }^{7}$ This strategy has been applied to identify integron-associated GCs in pure cultures, and it also has been coupled to cloning and nucleotide sequencing in order to characterize integron GCs in environmental samples. ${ }^{17,32-36}$

Amplicon analysis based on application of high-throughput next-generation sequencing-based technologies is increasingly applied for comprehensive characterization of environmental microbiomes. While this methodology has primarily been applied to target the 16S rRNA gene to assess bacterial community composition in the environment, ${ }^{37}$ it has also been used for high throughput screening of functional genes. ${ }^{38}$ In this paper we apply a novel Illumina-based amplicon sequencing pipeline that enabled characterization of hundreds of thousands of integron-associated genes per sample. We used this method to assess integron GC composition in effluents from 12 different WWTPs across Europe. Furthermore, we applied this approach to determine the composition of integron associated genes in effluent-saturated and pristine soils in order to assess the impact of effluent discharge in downstream environments. We specifically focused on $\beta$-lactamase-encoding genes in these samples due to fact that they are the most prevalent single cause of bacterial resistance to $\beta$-lactam antibiotics and that they are often associated with multidrug resistance.

\section{MATERIALS AND METHODS}

Sampling. Composite $(24 \mathrm{~h})$ effluent samples were collected on the 14th, 15th and 16th of October, 2014 from 12 urban WWTP facilities across Europe (Figure 1; Table 1).

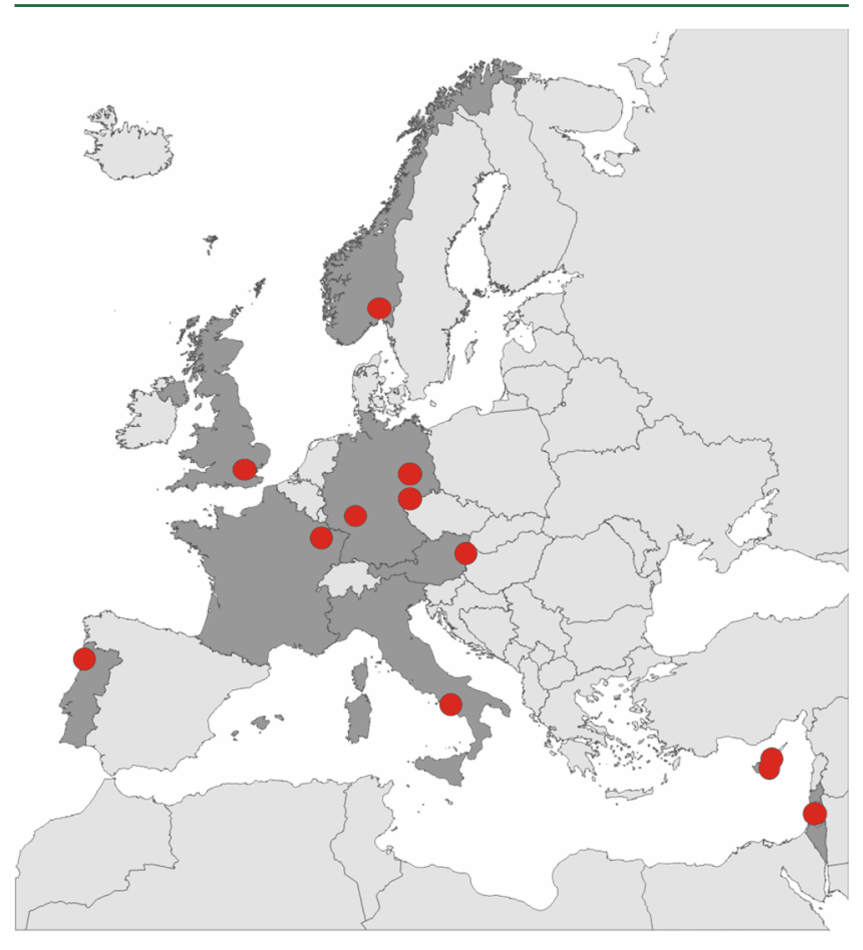

Figure 1. Geographic locations of WWTPs sampled in this study. Targeted WWTPs are shown in red circles.

On each day, the samples were transferred on ice (within $2 \mathrm{~h}$ ) to local laboratories, where three $150 \mathrm{~mL}$ aliquots were filtered through polycarbonate membrane filters $(0.22 \mu \mathrm{m})$ and stored at -20 to $-80{ }^{\circ} \mathrm{C}$ prior to DNA extraction. DNA was extracted from the filters (a total of three per site) using the PowerWater DNA Isolation kit (Mo Bio Laboratories Inc., Carlsbad, CA) according to the manufacturer's instructions, and samples from each of the sites were pooled, resulting in a single sample from each of the 12 effluents. The extracted DNA was used as a template for PCR of integron GCs as described below.

The Shafdan WWTP in Israel applies saturated aquifer treatment (SAT), ${ }^{39}$ where secondary effluent is pumped into large reservoirs (infiltration ponds) and percolates through the vadose zone to a deep aquifer. Four samples were taken from this facility to compare wastewater sludge, effluent and soil from within, and adjacent to an infiltration pond receiving Shafdan effluent. Sludge and soils were sampled on July 22nd, 2014 (soils were damp from residual effluent), and effluent was sampled from July 22nd, 23rd, and 24th, 2014 and filtered as described above. DNA extraction of effluents was performed as described above, whereas DNA from dewatered sludge and soil 
Table 1. WWTPs Sampled in This Study ${ }^{a}$

\begin{tabular}{|c|c|c|c|c|c|c|}
\hline WWTP code & country & city & coordinates (Lat) & coordinates (Lon) & characteristics & remarks \\
\hline NO & Norway & Slemmestad & $59^{\circ} 47^{\prime} 36^{\prime \prime} \mathrm{N}$ & $10^{\circ} 29^{\prime} 59^{\prime \prime} \mathrm{E}$ & $\mathrm{C} / \mathrm{N} / \mathrm{DN} / \mathrm{P}$ & SEC \\
\hline UK & England & London & $51^{\circ} 37^{\prime} 26^{\prime \prime} \mathrm{N}$ & $0^{\circ} 2^{\prime} 12^{\prime \prime} \mathrm{W}$ & $\mathrm{C} / \mathrm{N} / \mathrm{DN} / \mathrm{P}$ & SEC \\
\hline DE1 & Germany & Plauen & $50^{\circ} 31^{\prime} 29^{\prime \prime} \mathrm{N}$ & $12^{\circ} 10^{\prime} 5^{\prime \prime} \mathrm{E}$ & $\mathrm{C} / \mathrm{N} / \mathrm{DN} / \mathrm{P}$ & SEC \\
\hline DE2 & Germany & Dresden & $51^{\circ} 04^{\prime} 14^{\prime \prime} \mathrm{N}$ & $13^{\circ} 40^{\prime} 51^{\prime \prime} \mathrm{E}$ & $\mathrm{C} / \mathrm{N} / \mathrm{DN} / \mathrm{P}$ & SEC \\
\hline DE3 & Germany & Leipzig & $51^{\circ} 21^{\prime} 23^{\prime \prime} \mathrm{N}$ & $12^{\circ} 20^{\prime} 32^{\prime \prime} \mathrm{E}$ & $\mathrm{C} / \mathrm{N} / \mathrm{DN} / \mathrm{P}$ & SEC \\
\hline FR & France & Grand Nancy & $48^{\circ} 42^{\prime} 44^{\prime \prime} \mathrm{N}$ & $6^{\circ} 10^{\prime} 27^{\prime \prime} \mathrm{E}$ & $\mathrm{C} / \mathrm{N} / \mathrm{DN} / \mathrm{P}$ & SEC \\
\hline PT & Portugal & Maia & $41^{\circ} 12^{\prime} 17^{\prime \prime} \mathrm{N}$ & $8^{\circ} 35^{\prime} 41^{\prime \prime} \mathrm{W}$ & $\mathrm{C}$ & SEC \\
\hline IT & Italy & Salerno & $40^{\circ} 37^{\prime} 59^{\prime \prime} \mathrm{N}$ & $14^{\circ} 50^{\prime} 22^{\prime \prime} \mathrm{E}$ & $\mathrm{C} / \mathrm{N} / \mathrm{P}$ & EBPR; SEC; DI \\
\hline CY1 & Cyprus & Limassol & $34^{\circ} 44^{\prime} 0^{\prime \prime} \mathrm{N}$ & $33^{\circ} 12^{\prime} 0^{\prime \prime} \mathrm{E}$ & $\mathrm{C} / \mathrm{N} / \mathrm{DN} / \mathrm{P}$ & EBPR; SEC; DI \\
\hline $\mathrm{CY} 2$ & Cyprus & Nicosia & $35^{\circ} 8^{\prime} 33^{\prime \prime} \mathrm{N}$ & $33^{\circ} 28^{\prime} 33^{\prime \prime} \mathrm{E}$ & $\mathrm{C} / \mathrm{N} / \mathrm{DN} / \mathrm{P}$ & EBPR; MEM \\
\hline IL & Israel & Rishon Lezion & $31^{\circ} 57^{\prime} 22^{\prime \prime} \mathrm{N}$ & $34^{\circ} 44^{\prime} 15^{\prime \prime} \mathrm{E}$ & $\mathrm{C} / \mathrm{N} / \mathrm{DN} / \mathrm{P}$ & EBPR; SEC \\
\hline
\end{tabular}

${ }^{a}$ Details. C: carbon removal; N: nitrification; DN: denitrification; P: phosphorus removal; EBPR: enhanced biological phosphorus removal; SEC: secondary clarifier; MEM: membranes for solid separation; DI: effluent disinfection step with Chlorine.

samples was extracted using the PowerSoil DNA Isolation kit (Mo Bio Laboratories Inc., Carlsbad, CA) according to the manufacturer's instructions. DNA from all samples was stored at $-80{ }^{\circ} \mathrm{C}$ until further analysis.

PCR Amplification of Gene Cassettes and Selected $\boldsymbol{\beta}$ Lactamase Genes. Amplification of integron GCs was based on the protocol described by Stokes et al., which targets the 59-base element family of recombination sites that flanks the GCs, using the HS286 and HS287 primers. Negative controls were included in all of the GC PCR amplification reactions, and only reactions without amplification products in the negative controls were used for sequencing.

Library Preparation and Sequencing. Initially, barcoded libraries were prepared using $1 \mathrm{ng}$ of PCR product with the Nextera XT DNA Library preparation Kit (Illumina) according to protocols provided by the manufacturer. Following this stage, the libraries of the 12 WWTP effluent samples and four Shafdan samples were sequenced at the University of Illinois, Chicago DNA services facility (www.rrc.uic.edu/dnas) and The Technion Genome Center (Haifa, Israel) (http://tgc.net. technion.ac.il/) respectively, using Illumina paired end sequencing technology on a MiSeq desktop sequencer (Illumina).

Construction of a Comprehensive $\boldsymbol{\beta}$-Lactamase Database. Inclusive characterization of integron-associated $\beta$ lactamase genes was preceded by construction of an extensive $\beta$-lactamase database (EX-B) that integrated four clinically important publically available databases: The Lahey $\beta$-lactamase database, ${ }^{40,41}$ The Lactamase Engineering Database (LACED), ${ }^{42}$ The Comprehensive Antibiotic Resistance Database (CARD) ${ }^{43}$ and The Pasteur Institute's OXY, OKP and LEN protein variation databases (http://bigsdb.web.pasteur.fr/ perl/bigsdb/bigsdb.pl? db=pubmlst_klebsiella_seqdef public\&page $=$ downloadAlleles). All of the sequences deposited into EX-B were compared using BioEdit 7.2.5 software and checked for nonredundant sequences; producing a database containing 1566 nonredundant $\beta$-lactamase sequences. The EX-B database is publically available for download at (http:// app.agri.gov.il/eddie/tools.html).

Classification of Integron Gene Cassette Amplicons. Illumina amplicon reads were initially filtered to remove ambiguities with Mothur v1.35.1. ${ }^{44}$ Subsequently, filtered contigs (see below) and amplicon sequences were compared to five different databases using the blastx ${ }^{45}$ and Diamond ${ }^{46}$ algorithms at an e-value cutoff of $10^{-5}$ (preliminary analysis determined that both algorithms gave very similar results, but Diamond was significantly faster). The NCBI nonredundant (nr) protein database ${ }^{472}$ and SEED $^{48}$ were used to acquire an overall classification of the amplicon reads and assembled contigs; the Antibiotic Resistance Genes Database (ARDB) ${ }^{49}$ was applied to classify antibiotic resistant genes; while the EX-B database was used to comprehensively characterize $\beta$ lactamases.

The nr, SEED and ARDB gene characterizations were based on amino acid read identities of $\geq 40 \%$ and alignment length $\geq 40$ amino acids. ${ }^{50} \beta$-lactamase gene amplicons were defined according to an identity of $50 \%$ or more; an e-value lower than $10^{-5}$ and a bit score higher than 30 . The $\beta$-lactamase genes were further characterized based on $51-75 \%, 76-89 \%$ and $>90 \%$ identity cutoffs in attempt to differentiate between clinically associated genes, and environmental $\beta$-lactamase genes, which are often diverse relative to clinically characterized $\beta$-lactamases. ${ }^{51}$ Following filtration and classification, the blastx/DIAMOND hits for all gene subtypes were imported into tables to determine relative abundance and diversity; finally, the data was normalized by multiplying hits for a given category by a coefficient which was obtained by dividing the total amount of reads in a given sample by the average number of reads for all samples.

Assembly of the filtered contigs described above was performed using the metAMOS 1.5 assembly pipeline ${ }^{52}$ with the Meta-IDBA algorithm. ${ }^{53}$ Different $k$-mers (31 to 101 ) were assessed and the best solution ( $k$-mer of 91$)$ was identified by QUAST (Supporting Information (SI) Table S1). ${ }^{54}$ The assembled contigs were used to identify GC-associated genes using blastx and DIAMOND as described above. Due to the relatively low number of assembled reads, $\beta$-lactamase hits presented in this study were only based on high quality reads and not on assembled contigs.

Validation Experiments. Composition of GC amplicon sequences were validated using the following protocol: PCR amplicons from the Shafdan effluent sample (generated using the HS286 and HS287 primers) were cloned into PGEM Teasy vectors (Promega, Madison, WI), subsequently transformed into E. coli DH5 $\alpha$ competent cells and plated on selective LB media as recommended by the manufacturer. Plasmids were then extracted from four randomly selected positive colonies, subsequently sequenced using conventional Sanger sequencing and compared to the INTEGRALL integron gene database $^{55}$ using the BLAST algorithm (SI Table S2). 


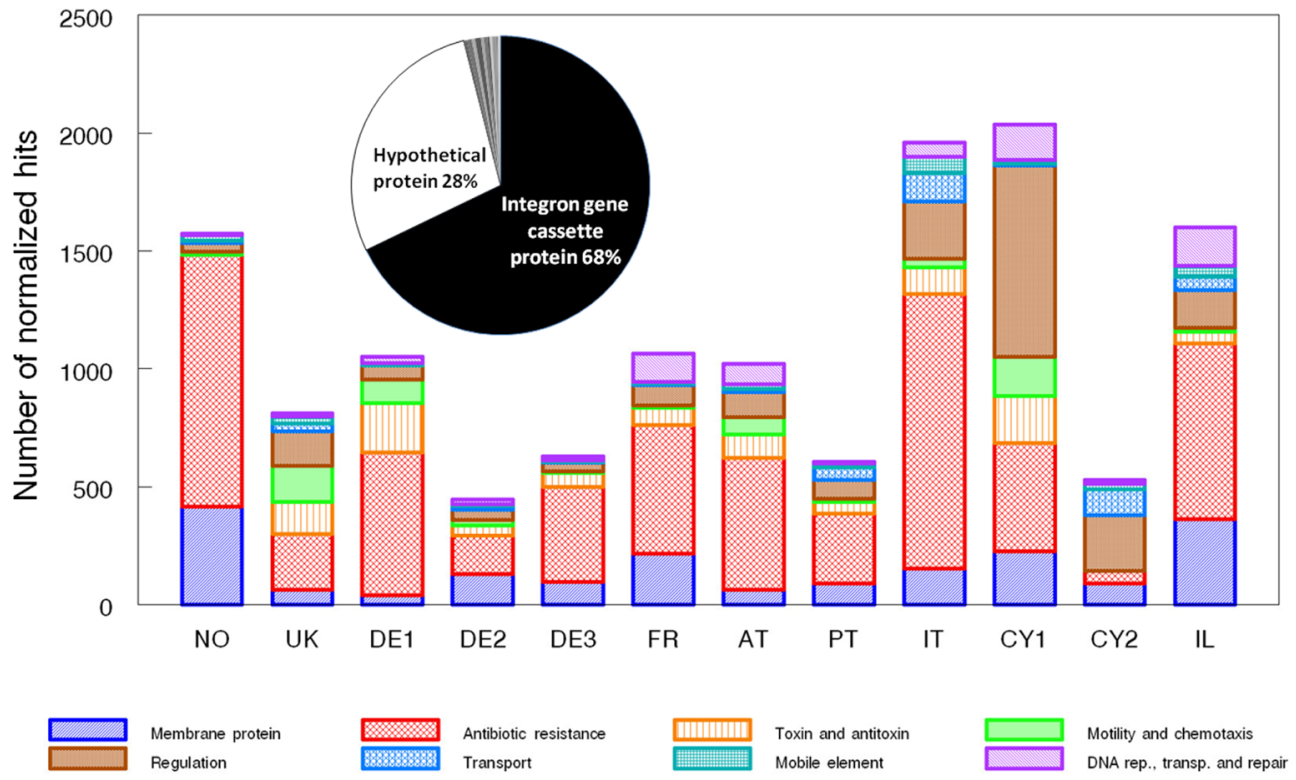

Figure 2. Abundance of the most dominant integron-associated genes in the 12 targeted European WWTP effluents based on comparisons to the NCBI nonredundant (nr) protein database. Pie chart insert: distribution of all genes in the effluents from the 12 analyzed WWTPs; bar chart: distribution of characterized (nonhypothetical) functional gene categories. Gene abundances were normalized to the average number of total reads for each sample. Legend: DNA rep., transp. and repair = DNA replication, transport and repair.

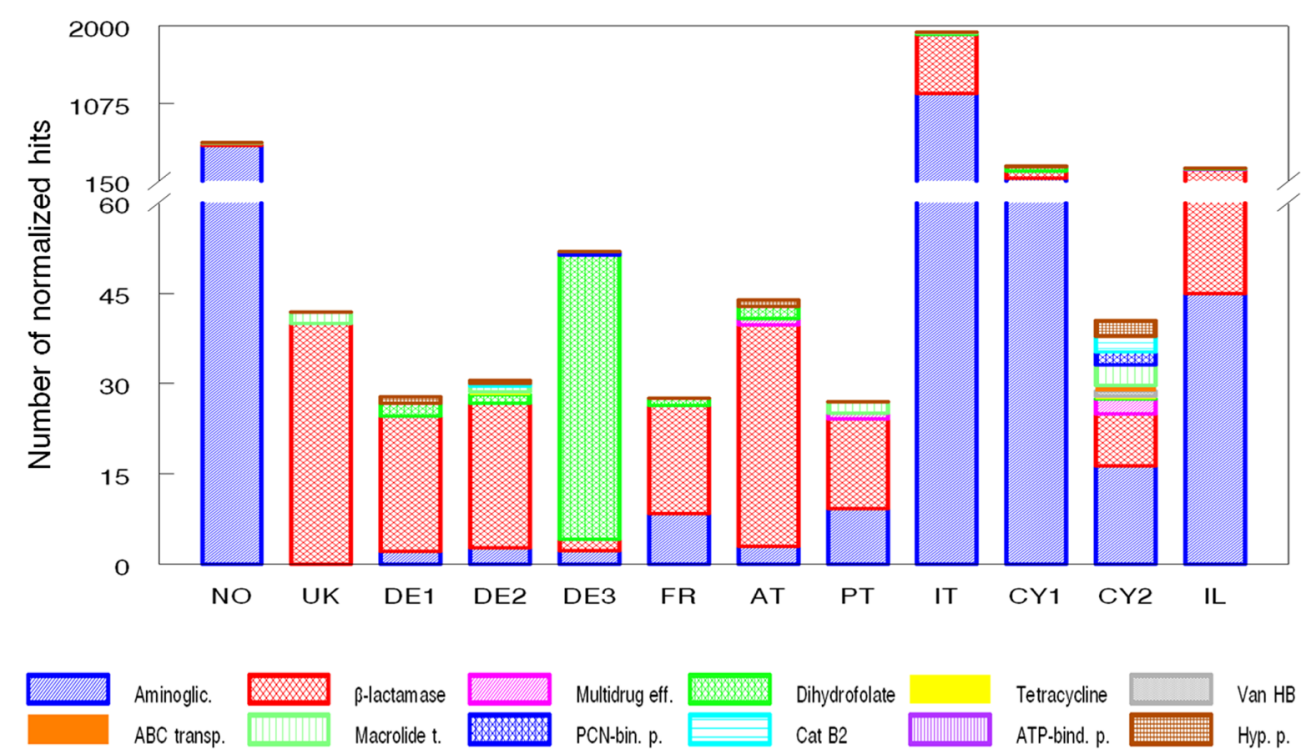

Figure 3. Abundance of the most dominant integron-associated antibiotic resistance mechanisms in the 12 targeted European WWTP effluents based on comparisons to the Antibiotic Resistance Gene Database. Gene abundances were normalized to the average number of total reads for each sample. Legend: Aminoglic. $=$ Aminoglicoside; Multidrug eff. $=$ Multidrug efflux, $\mathrm{ABC}$ transp. $=\mathrm{ABC}$ transporter; Macrolide $\mathrm{t} .=$ Macrolide transporter; PCN-bin. p.= Penicillin-binding protein; ATP-bind. p.= ATP-binding protein, and Hyp. $\mathrm{p} .=$ Hypothetical protein.

Results from the EX-B database analyses (see below) were validated by conventional and quantitative real-time PCR analyses targeting $b l a_{\mathrm{OXA}-2}, b l a_{\mathrm{OXA}-10}$, and $b l a_{\mathrm{GES}}$, the most abundant $\beta$-lactamase genes identified in the integron amplicon sequencing analysis. The primers and PCR conditions used for all of the above analyses are summarized in SI Table S3.

Sequence Accession Numbers. The sequences generated in this study were deposited in the European Nucleotide Archive (ENA) under accession numbers ERS1030613ERS1030628.

\section{RESULTS}

The novel next generation amplicon sequencing-based methodology developed here generated between 38,100 to 172,995 high quality reads per sample for the 12 European effluent and four Shafdan samples (SI Tables S4 and S5). These reads were compared to different databases in order to comprehensively characterize and assess the relative abundance of integron GCassociated coding sequences in the various samples.

Characterization of Integron-Associated Genes in European WWTP Effluents. Functional characterization of the GC reads in the 12 WWTP effluents was inferred by blasting sequences against the $\mathrm{nr}$ (SI Table S6) and SEED (SI 


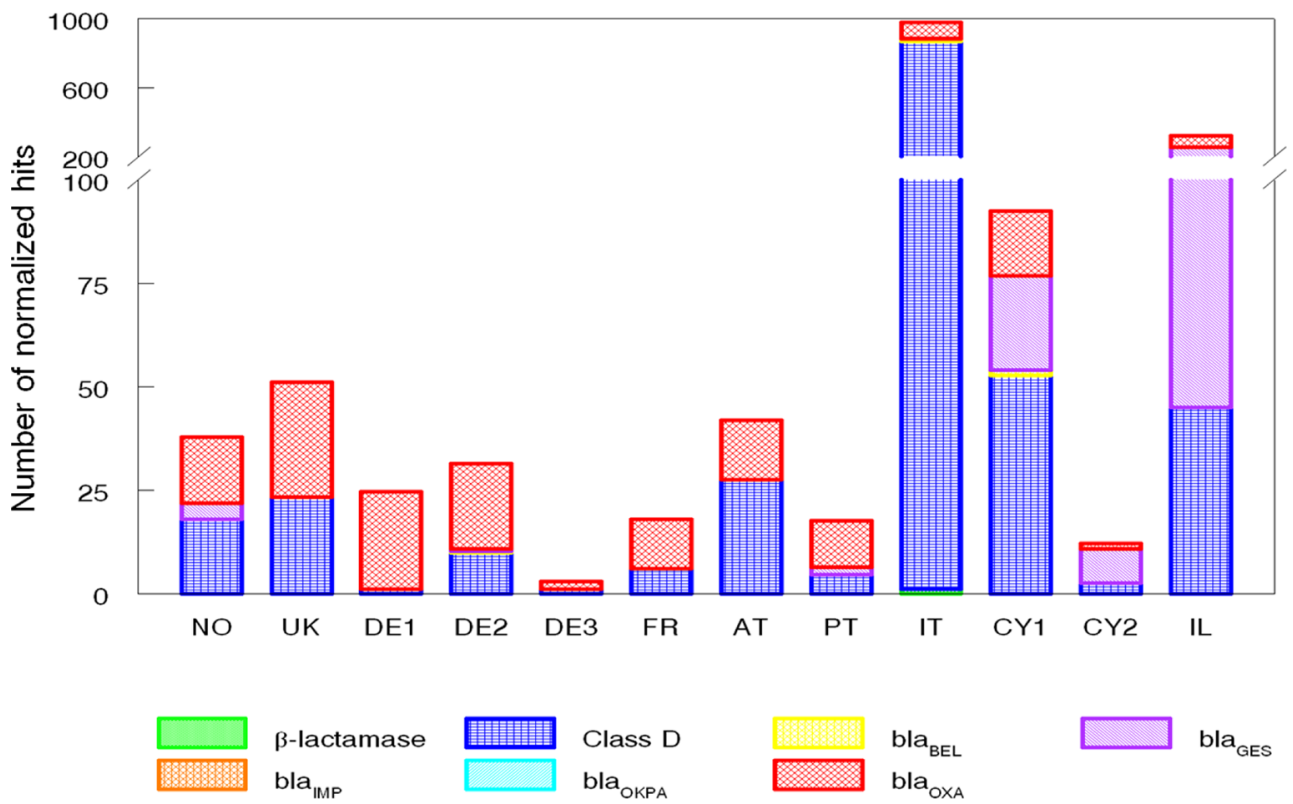

Figure 4. Abundance of $\beta$-lactamases in integrons from the 12 European WWTPs based on comparisons to the EX-B database. Gene abundances were normalized to the average number of total reads for each sample.
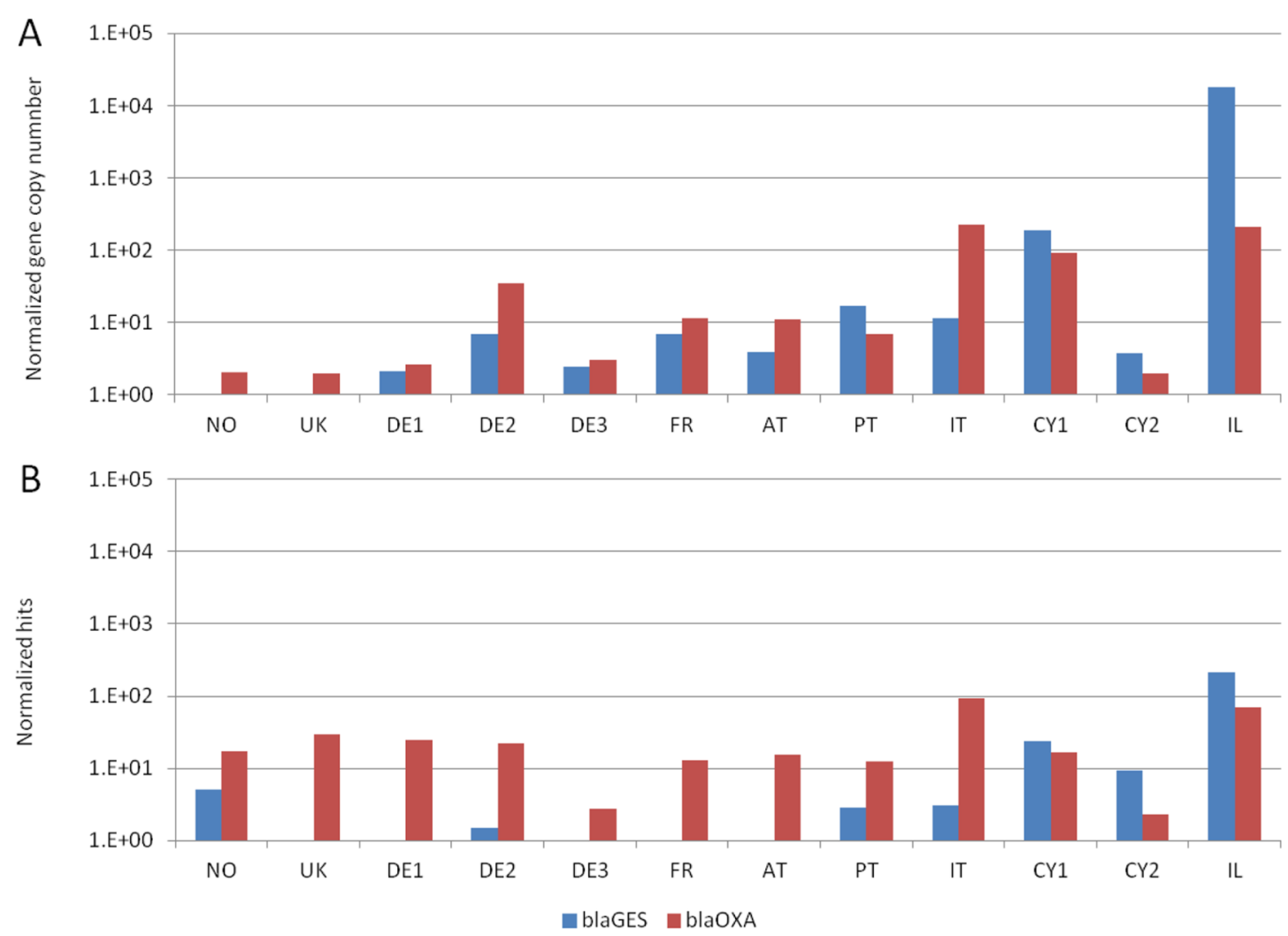

Figure 5. Abundance of $b l a_{\mathrm{OXA}}$ and $b l a_{\mathrm{GES}}$ genes in integrons, in European effluents. (A) Gene copy number according to qPCR results. (B) Hits identified based on the comparison to the EX-B $\beta$-lactamase database. Gene abundances were normalized to the average number of total reads for each sample.

Table S7) databases. This revealed a broad array of genes with diverse putative functionality. Between $12-71 \%$ and $50-82 \%$ of the reads in all of the samples were predicted to encode for hypothetical proteins according to the $\mathrm{nr}$ and SEED databases, respectively. These included between 13 and $86 \%$ hypothetical proteins that were specifically defined by the $\mathrm{nr}$ database as putative integron gene cassette proteins based on a previous study by Koenig et al. ${ }^{56}$ Between $0.47-3.2 \%$ (nr) and $0.84-$ $3.8 \%$ (SEED) of the all generated reads encoded functionally characterized proteins. These were associated with a myriad of functions including antibiotic resistance and biosynthesis, transport, membrane proteins, toxin/antitoxin systems, mobile element functions, and transcriptional regulation (Figure 2). 


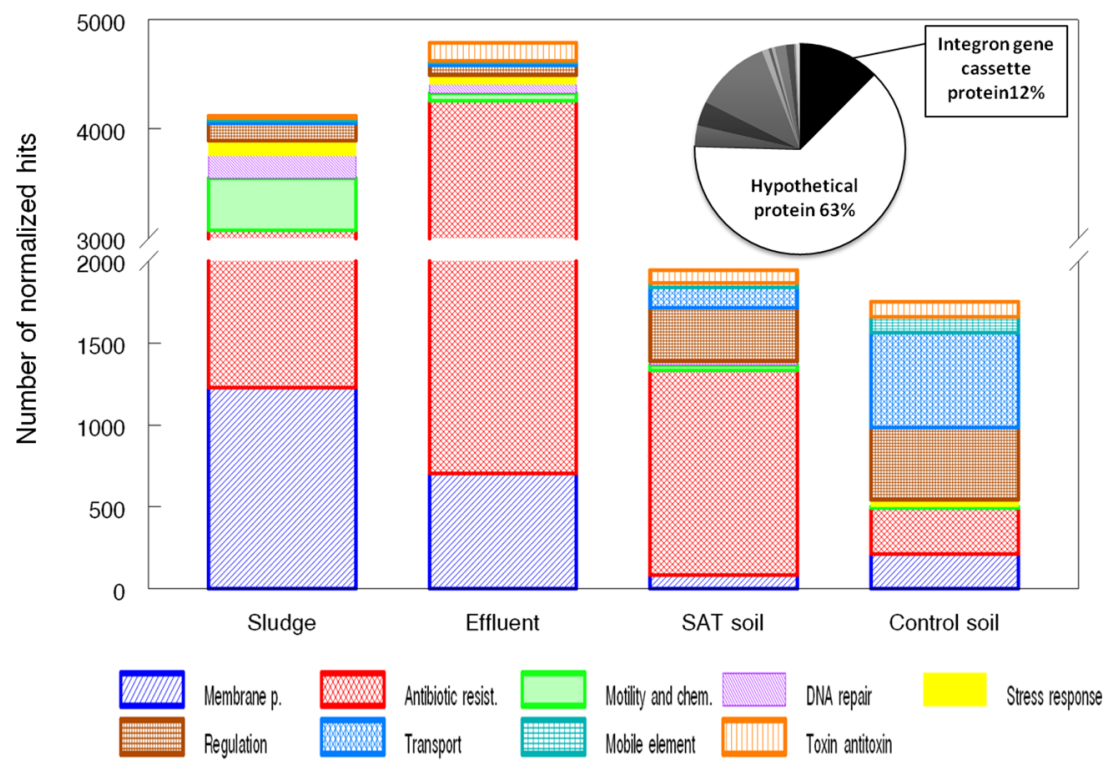

Figure 6. Abundance of the most dominant integron-associated genes across the four Shafdan sites samples based on comparisons to the NCBI nonredundant (nr) protein database. Pie chart insert: distribution of all genes in the Shafdan sites; bar chart: distribution of characterized (nonhypothetical) functional gene categories. Gene abundances were normalized to the average number of total reads for each sample. Legend: Menbrane p.= Membrane protein; Antibiotic resist.= Antibiotic resistance, and Motility and chemo.= Motility and chemotaxis.

Screening GC amplicons against the ARDB database showed high relative abundance of genes encoding $\beta$-lactamases, aminoglycoside acetyltransferases, aminoglycoside adenyltrasnferases and dihydrofolate reductases (Figure 3; SI Table S8). Collectively, $\beta$-lactamase encoding genes were the dominant GC-associated antibiotic resistance elements in AT, DE1, DE2, FR, IL, PT, and UK effluents; aminoglycosides resistance mechanisms were most prominent in CY1, CY2, NO, and IT effluents; and dihydrofolate reductases were abundant in the DD3 effluents.

Due to their abundance and clinical importance, we specifically targeted $\beta$-lactamases by comparing generated GC amplicon reads to the newly compiled EX-B database described above (SI Table S9). In total, $0.009 \%$ to $1.04 \%$ of the integron GC-associated reads in the 12 WWTP effluents were characterized as $\beta$-lactamases, which represented on average $14.17 \%$ or $52.59 \%$ of the characterized antibiotic resistance genes according to the $\mathrm{nr}$ and ARDB databases, respectively. The IT effluent GCs contained the highest relative abundance of $\beta$-lactamases, followed by the IL, CY1 and DE2 effluents (Figure 4). A large number of $\beta$-lactamases could not be assigned to specific gene families, and therefore an analysis based on general molecular $\beta$-lactamase classification ${ }^{41}$ was performed (SI Table S10 and Figure S1). Class D was by far the most abundant class identified in 10 of the 12 effluent samples (relative abundance of $74-100 \%$ of total $\beta$-lactamase genes); whereas CY2 and IL effluents were dominated by class A $(67.8 \%$ and $64.9 \%$ vs $32.1 \%$ and $35 \%$, respectively for class D). We further characterized specific variants of $b l a_{\text {OXA }}$ and $b l a_{\mathrm{GES}}$, the two dominant $\beta$-lactamase genes detected in the 12 analyzed effluents (SI Tables S11 and S12, respectively). The $b l a_{\text {OXA }}$ gene family (class D) was detected in all of the WWTP effluents (relative abundance of $0.0046 \%$ to $0.1 \%$ ), whereas $b l a_{\mathrm{GES}}$ (class A) and $b l a_{\mathrm{BEL}}$ were present in seven (relative abundance of $0.0011 \%$ to $0.21 \%)$ and three $(0.0009 \%$ to $0.013 \%)$ of the WWTP effluents, respectively. The $\beta$-lactamase genes $b l a_{\mathrm{IMP}}$ and $b l a_{\mathrm{OKPA}}$ were only detected in the IT effluent. Although many of the amplicons could not be characterized to the variant level, we determined that $b l a_{\text {OXA }}$ groups 2 and 10 and $b l a_{\mathrm{GES}} 8$ were the dominant variants of these two families.

Quantitative real-time PCR (qPCR) targeting $b l a_{\mathrm{OXA}}$ and $b l a_{\mathrm{GES}}$ genes in the 12 analyzed WWTP effluents was applied to validate the EX-B amplicon sequencing results described above (SI Figure S2; Figure 5). Despite certain discrepancies, similar trends in the relative abundance of the two $\beta$-lactamase genes were observed.

Source Tracking of Integron-Associated Genes in Effluent-Impacted and Pristine Soils. As observed in the effluent samples, most of the GC amplicon reads in the Shafdan samples were defined as hypothetical and putative integronassociated proteins with no characterized function (Figure 6). Nonetheless, a myriad of functionally characterized reads were identified by $\mathrm{nr}$ (SI Table S13) and SEED (SI Table S14) database comparisons. High relative abundances of $\beta$-lactamase and glyoxalase encoding genes were detected in the dewatered sludge and effluent samples vs negligible presence of these genes in the infiltration pond and control soils. In contrast, aminoglycoside acetyltransferases were detected in amplicons from all four samples. Genes encoding toxin-antitoxin and killer proteins, associated with plasmid maintenance, were found in almost all of the samples, but toxin proteins were dominant in both infiltration pool and control soil samples; whereas killer proteins were most abundant in the effluent sample. These plasmid maintenance-associated elements were previously identified in integron gene cassettes from contaminated Suez Bay sediment. ${ }^{57}$ The control soil contained high relative abundances of cupins and mobile elements relative to sludge and effluent samples. Cupin domains have been observed in biofilm-isolated integrons, ${ }^{58}$ and have been found to be involved in transcriptional responses to diverse stress signals, ${ }^{59}$ but their actual function is currently unknown.

Screening the GC reads against the ARDB databases revealed $\beta$-lactam, aminoglycoside, macrolide, vancomycin, quinolone and multidrug resistance mechanisms in the various Shafdan samples (SI Table S15). The $\beta$-lactamase- and aminoglycoside adenyltransferase-encoding genes were substantially more 


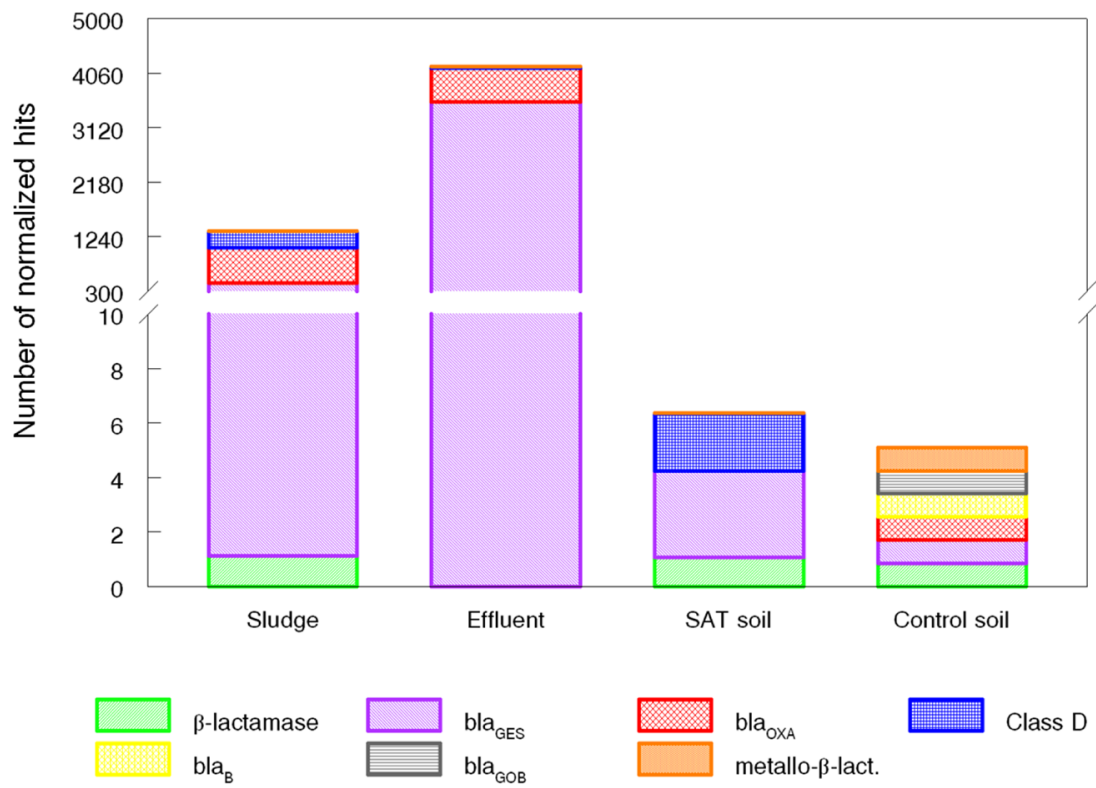

Figure 7. Abundance of $\beta$-lactamases in integrons across the four Shafdan sites based on comparisons to the EX-B database. Gene abundances were normalized to the average number of total reads for each sample. Legend: metallo- $\beta$-lact. $=$ metallo- $\beta$-lactamase.

abundant in the effluent and sludge samples (1618 and 5776 reads respectively), whereas aminoglycoside-3N-acetyltransferases, macrolide, vancomycin, hypothetical and multidrug resistance mechanisms were more abundant in the soil samples (58 reads in SAT soil and 258 reads in control soil).

The distribution of integron-associated $\beta$-lactamase genes assessed based on the EX-B database querying revealed similar trends in the July 2014 and October 2014 Shafdan WWTP effluent samples (SI Tables S9 and S16). In contrast, the composition and the relative abundance of GC-associated $\beta$ lactamase genes in the dewatered sludge were substantially different than the effluents despite that fact that these two samples were from the same sampling date. The abundance of $\beta$-lactamases in the dewatered sludge and effluent samples was considerably higher than in the infiltration pool and the control soils (Figure 7). A total of 1200 and 4,342 reads were characterized as $\beta$-lactamases in the sludge and effluent samples, representing $0.9 \%$ and $3.8 \%$ of all integron-associated reads, respectively. In contrast, only six hits were observed in both the SAT soil and the control soils $(0.004 \%$ and $0.006 \%$ of all identified reads, respectively).

The $\beta$-lactamases identified in all of the analyzed samples were further screened against the EX-B database using three levels of stringency: $50-75 \% ; 76-89 \%$, and $>90 \%$ (SI Tables S17 and S18, Figures S3 and S4). The majority of integronassociated $\beta$-lactamases in most of the WWTP effluents, the Shafdan sludge and the soil from the Shafdan infiltration pool were $>90 \%$ identical to clinically derived $\beta$-lactamases from the database. In contrast, none of the control soil $\beta$-lactamases were a nonanthropogenic source of these genes.

As previously described, many reads could not be classified to specific $\beta$-lactamase gene families and therefore we again reanalyzed the $\beta$-lactamase gene data according to molecular classes (SI Figure S5). Approximately $68 \%$ of all $\beta$-lactamases in the dewatered sludge sample and $14.3 \%$ in the effluent sample were associated with class D $\beta$-lactamases, while $32.4 \%$ and $85.6 \%$, respectively were associated with class $\mathrm{A}$.

The analysis of hits assigned to specific $\beta$-lactamase gene families was in agreement with what was observed in the
European final effluents; $b l a_{\mathrm{GES}}$ and $b l a_{\mathrm{OXA}}$ were the exclusive and dominant $\beta$-lactamases in the dewatered sludge and effluents of the Shafdan WWTP. However, $b l a_{\text {OXA }}$ was more abundant in the dewatered sludge sample $(0.4 \%$ vs $0.2 \%$ for $\left.b l a_{\mathrm{GES}}\right)$; whereas $b l a_{\mathrm{GES}}$ was more abundant in the effluent sample (3.2\% relative abundance vs $0.5 \%$ for $\left.b l a_{\text {OXA }}\right)$. Extremely low relative abundance of $b l a_{\mathrm{GES}}(0.002 \%)$ was detected in the SAT soil.

PCR analysis targeting $b l a_{\mathrm{OXA}}$ and $b l a_{\mathrm{GES}}$ genes was conducted for the four Shafdan samples in order to validate EX-B-based characterization of the GC amplicons described above (SI Figure S2). These genes were profuse in both sludge and effluent samples, only faintly detected in the SAT soil and were below detection limit in the control soils, validating results obtained in the integron GC amplicon sequencing analysis described above.

\section{DISCUSSION}

The increasing realization that antibiotic resistance in the environment may have significant public health and environmental ramifications necessitates the development of methodologies for evaluating the composition and abundance of ARGs in the environment. This is especially pertinent to anthropogenic hotspots like WWTPs and animal husbandry facilities that are believed to disseminate ARGs to downstream aquatic and terrestrial environments, especially for ARGs that are associated with MGEs and gene acquisition elements such as plasmids and integrons that can be mobilized across ecological and phylogenetic boundaries.

Although integrons are believed to be important vectors of ARGs in anthropogenic environments, it is challenging to monitor GC-associated genes in complex environmental samples due to limitations of currently applied cultureindependent methodologies. This is strongly supported by Koenig et al., ${ }^{60}$ who performed the most exhaustive analysis of integron GCs in environmental samples to date. The authors screened 1400 gene cassettes from different marine sediments, however, rarefaction curves revealed that only a small fraction of the GC diversity was covered indicating that more robust 
analyses are required. This argument is augmented given the fact that close to $75 \%$ of the sequences analyzed in this study were characterized as conserved hypothetical proteins, so only a small fraction of coding sequences could actually be functionally characterized. The highly robust, integron gene cassette amplicon sequencing pipeline described in this paper sheds new light on the mobile resistome in WWTP effluents and receiving downstream environments. Although this pipeline has certain limitations due to PCR biases associated with amplicon read length variation, and the fact that PCR primers amplify an array of known integron gene cassettes and not just those associated with anthropogenic environments, it revolutionizes our capacity to characterize integron GCs in natural environments.

Comparative Analysis of Integron Gene Cassettes in WWTP Effluents. Integrons are often associated with antibiotic resistance in pathogens, ${ }^{19,26}$ and therefore special attention was placed on characterizing integron-associated ARGs in this study. The dominant GC-associated ARGs in the effluent samples (identified in at least 10 of the 12 WWTP effluents at relative abundances greater than $0.1 \%$ ) encoded acetyltransferases that confer resistance to aminoglycosides; glyoxalases, implicated in resistance to the glycopeptide bleomycin; and $\beta$-lactamases. These antibiotic resistance gene families have been previously detected in integron GCs from a diverse array of environments including polluted marine sediments, ${ }^{57}$ coral mucus, ${ }^{60}$ soil,,${ }^{61}$ and WWTPs. ${ }^{30}$ While the primers applied in this study are not confined to one class of integron GCs, previous studies have revealed high abundance of class 1 integrons in WWTP effluents relative to other integron classes, suggesting a strong linkage between ARGs and class 1 integrons in WWTP effluents. ${ }^{25,26}$

We focused on $\beta$-lactamases due to their abundance, association with mobile genetic elements and their clinical relevance. Over $90 \%$ of the GC-associated $\beta$-lactamases in all 12 analyzed European effluents were associated with either the $b l a_{\mathrm{OXA}}$ (class D) or $b l a_{\mathrm{GES}}$ (class A) families. $b l a_{\mathrm{OXA}}$, collectively the most dominant $\beta$-lactamase in the European WWTP effluents, has been previously reported in a myriad of studies that assessed ARGs in WWTPs ${ }^{25,62-66}$ This family is considered to be of clinical importance because certain variants display extended spectrum activity against both carbapenems and third-generation cephalosporins. ${ }^{67}$ In contrast, $b l a_{\mathrm{GES}}$ was primarily detected in the CY and IL effluents. This "minor extended-spectrum $\beta$-lactamase" gene family has been increasingly reported in Gram-negative rods in clinical samples from around the globe. It encodes enzymes capable of hydrolyzing carbapenems and is less susceptible to inhibitors than other ESBLs, ${ }^{68}$ making it a potential epidemiological threat. Integrons carrying $b l a_{\mathrm{GES}}$ have been previously detected in clinical Pseudomonas aeruginosa and Enterobactereaceae isolates, ${ }^{69-73}$ and were also reported in activated sludge from German ${ }^{74}$ and Portuguese WWTPs. ${ }^{66,75}$ Our results suggest that integrons carrying $b l a_{\mathrm{GES}}$ may be more abundant in the southeastern Mediterranean countries (Israel and Cyprus), however the specific factor associated with this phenomenon is not currently clear.

$b l a_{\mathrm{OXA}}$ and $b l a_{\mathrm{GES}}$ genes are frequently associated with class 1 integrons. For example, $17.2 \%$ of class 1 integrons $(n=1089)$ deposited in the integron database ${ }^{55}$ (INTEGRALL http:// integrall.bio.ua.pt/?) harbor $b l a_{\mathrm{OXA}}$, while $2.9 \%$ of class 1 integrons harbor $b l a_{\mathrm{GES}}$. These genes are not observed in class 2 integrons $(\mathrm{n}=45)$ and are only present in a few documented class 3 integrons $(n=8)$. Therefore, while we cannot validate the source of integrons pinpointed in this study, it is logical that a large fraction of the $b l a_{\mathrm{OXA}}$ and $b l a_{\mathrm{GES}} \beta$-lactamases identified in this study are associated with class 1 integrons.

Validation of integron GC amplicon analyses using qPCR that specifically targeted $b l a_{\mathrm{OXA}}$ and $b l_{\mathrm{GES}}$ genes revealed similar trends in the distributions of these $\beta$-lactamases in the integron GC amplicons and qPCR analyses, strengthening the robustness of this method. Nonetheless, some discrepancies were found between the two methods. Discrepancies in $b l a_{\mathrm{OXA}}$ values may stem from the fact that in contrast to the highly conserved $b l a_{\mathrm{GES}}$ family, $b l a_{\mathrm{OXA}}$ is highly diverse and therefore it is not possible to target all of the variants with a single primer set. Our qPCR validation specifically targeted $b l a_{\text {OXA-2 }}$ and $b l a_{\text {OXA-10, }}$ because these variants were found to be most abundant in the integron GC amplicon analysis. Finally, detection of $b l a_{\mathrm{GES}}$ in the qPCR validation in samples (DE1, $\mathrm{DE} 3, \mathrm{FR}$, and AT) where it was not detected in the amplicon GC analysis, may be explained by the higher sensitivity of the qPCR method.

Although ARGs were ubiquitous to integrons in all of the WWTP effluents, the majority of the GCs contained genes with different functions and several of these genes have been previously documented in integrons. These included high abundance of motility related genes, which were recently identified in the integrons from the metagenome of human saliva; ${ }^{76}$ and toxin-antitoxin encoding genes, which were previously detected within integrons from both multidrug resistant Escherichia coli ${ }^{77}$ and Vibrio strains. ${ }^{78}$ It was recently suggested that toxin-antitoxin associated genes play a role in integron stabilization. ${ }^{78}$ Many samples of the effluent samples contained high abundances of genes encoding for "putative integron gene cassette proteins" that have been previously described in environmental integron gene cassettes. ${ }^{56}$ Although the function of these proteins is not known, they appear to contain tetratricopeptide repeat (TPR) motifs that mediate protein-protein interactions. $^{79}$

Comparative Analysis of Integron Gene Cassettes in WWTP Compartments and Effluent-Saturated soil. Effluents from both Shafdan profiles showed greater abundance of $b l a_{\mathrm{GES}}$ relative to $b l a_{\mathrm{OXA}}$, whereas $b l a_{\mathrm{OXA}}$ was the dominant $\beta$ lactamase gene in the dewatered sludge profile. These results suggest temporal uniformity of integrons in individual WWTP effluents and indicate that effluents and dewatered sludge harbor distinct microbiomes with different distribution of integron GCs. The differences between the effluent and sludge samples may be explained by variations in selective pressure in the two samples, by differences in dominant microbiomes or by different DNA extraction efficiencies in the aqueous and sludge matrices. Variation in class 1 integron frequency and GC composition in Enterobacteriaceae strains across three different WWTP treatment steps was previously reported by Mokracka et al., ${ }^{28}$ who also reported higher levels of $\beta$-lactam resistance genes in final effluents relative to of the previous stages of the wastewater treatment.

Comparison of the GCs in effluent and saturated soil revealed strong reductions in the relative abundance of $\beta$ lactamases, glyoxalases and acetyltransferases suggesting that a large fraction of bacteria harboring effluent-associated integrons did not survive and suggesting that the dissemination of integron-harboring MGEs to soil microbiomes is limited. This is supported by additional studies that have demonstrated extremely low survival rates of aqueously introduced strains in soil, and an inverse correlation between microbial diversity in 
the receiving environment and persistence of introduced bacteria. ${ }^{80,81}$ The reduction of detected $\beta$-lactamases in the soil sample may stem from biases in DNA extraction or in the presence of PCR inhibitors in the soil sample, although other integron-related ARGs were detected in these samples, suggesting that this is not the case.

Although integron-associated genes may not be readily disseminated in soil environments, the low levels of detected ARGs depicted in this study could theoretically become fixed in the soil microbiome under certain conditions. The GC $\beta$ lactamases in the infiltration soil samples were more identical to previously described clinically significant genes than those from the noninfiltrated (control) soils, suggesting "anthropogenic vs. "environmental" origins of the two soil GC $\beta$-lactamases, respectively. ARG-harboring GCs have been detected in rivers receiving hospital effluents, ${ }^{29}$ suggesting a potentially significant environmental and epidemiological impact of integrons disseminated to aquatic environments.

On the whole, our data analysis of the Shafdan WWTP confirms traditional methodology-based studies $9,21,25,66,82,83$ indicating that WWTPs are important reservoirs of integrons. Nonetheless, the spread of integrons from WWTPs to soil environments appears to be limited.

Application of Methodology for Future Source Tracking Studies. A myriad of studies have recently targeted the intI1 integrase gene as a proxy for anthropogenic pollution, especially in and downstream of hotspots such as WWTPs, hospitals and animal husbandry facilities. ${ }^{9}$ This however does not reveal the actual genes that are associated with these integrons. The novel methodology presented in this study provides a simple high-throughput pipeline for tracking GCs in integrons and it can be developed to target GCs of specific classes as well. In addition, this method can be made significantly more robust by applying next generation sequencing technologies that generate large read lengths (i.e., Pacific Biosystems), which should reveal whole GC sequences.

Quantitative real-time PCR is often applied to determine the abundance of antibiotic resistance genes in effluents and in downstream environments, ${ }^{14}$ however it is often challenging to determine specific target ARGs that are most suitable for source tracking and in some studies it seems that they are arbitrarily chosen. Furthermore, target ARGs may be very abundant in background environments ${ }^{84}$ and therefore it is not possible to determine the impact of anthropogenic sources on aquatic and terrestrial environments. The PCR and qPCR methodologies described here target $b l a_{\mathrm{OXA}}$ variants and $b l a_{\mathrm{GES}}$ which we have shown to be among the most prevalent GC-associated $\beta$ lactamase genes in European WWTP effluents and are much less profuse in background environments. Collectively this suggests that these genes can be considered as excellent candidates for evaluating the impact of WWTPs on downstream resistomes. The strong association between class 1 integrons and $b l a_{\mathrm{OXA}}$ and $b l a_{\mathrm{GES}}$ genes suggests that they may also be used as proxies of class 1 integron abundance; however, more research needs to be done to validate this assumption.

\section{ASSOCIATED CONTENT}

\section{S Supporting Information}

The Supporting Information is available free of charge on the ACS Publications website at DOI: 10.1021/acs.est.6b03188.

Relative abundance of molecular classes of $\beta$-lactamases in integron gene cassettes in European WWTP effluents and Shafdan samples (Figures S1 and S5, respectively); Validation experiments showing agarose gels of PCR and qPCR products for $b l a_{\mathrm{OXA}}$ and $b l a_{\mathrm{GES}}$ genes (Figure S2); Distribution of $\beta$-lactamase hits in the European effluent and Shafdan samples based on \% similarity to EX-B database entries (figures S3 and S4, respectively); Contigs generated from assembly of integron GC reads (Table S1); Validation of integron gene cassette sequences based on cloning and Sanger sequencing (Table S2); Primers and PCR conditions applied in this study (Table S3); Number of high quality reads and $\beta$ lactamase hits obtained from European WWTP and Shafdan integron GCs (Tables S4 and S5, respectively); Prominent integron-associated genes in European WWTP effluents and Shafdan samples based on comparison to the $\mathrm{nr}$ database (Tables S6 and S13, respectively); Prominent integron-associated genes in European WWTP effluents and Shafdan samples based on comparison to the SEED database (Tables S7 and S14, respectively); Prominent integron-associated antibiotic resistance genes in European WWTP effluents and Shafdan samples based on comparison to the ARDB database (Tables S8 and S15, respectively); Prominent integron-associated $\beta$-lactamases in European WWTP effluents and Shafdan samples based on comparison to the EX-B database (Tables S9 and S16, respectively); Classification of $\beta$-lactamase genes according to molecular classes (Table S10); and Closest BLAST identities of gene cassette amplicon-associated $b l a_{\mathrm{OXA}}$ and $b l a_{\mathrm{GES}}$ in European effluents and Shafdan samples (Tables S11 and S12, respectively); Distribution of $\beta$-lactamase hits based on \% similarity to EX-B database entries in the European WWTP effluent samples and Shafdan samples (Tables S17 and S18, respectively) (PDF)

\section{AUTHOR INFORMATION}

\section{Corresponding Author}

*Phone: 972-050-6220083/972-03-9683767; e-mail: eddie@ volcani.agri.gov.il.

\section{Notes}

The authors declare no competing financial interest.

\section{ACKNOWLEDGMENTS}

This study was funded by the Israel Ministry of Agriculture Chief Scientist (grant \# 821-0000-13) and partially supported by the NORMAN association (www.norman-network.net). We thank Dr. Roy Elkayam for technical assistance and the COST NEREUS action for constructive discussions.

\section{REFERENCES}

(1) Center for Disease Dynamics, Economics \& Policy (CDDEP). State of the World's Antibiotics; CDDEP: Washington, D.C., 2015; pp 84.

(2) Moura, A.; Henriques, I.; Smalla, K.; Correia, A. Wastewater bacterial communities bring together broad-host range plasmids integrons and a wide diversity of uncharacterized gene cassettes. Res. Microbiol. 2010, 161, 58-66.

(3) Berendonk, T.; Manaia, C.; Merlin, C.; Fatta-Kassinos, D.; Cytryn, E.; Walsh, F.; Bürgmann, H.; Sørum, H.; Norström, M.; Pons, M.; Kreuzinger, N.; Huovinen, P.; Stefani, S.; Schwartz, T.; Kisand, V.; Baquero, F.; Martinez, J. Tackling antibiotic resistance: the environmental framework. Nat. Rev. Microbiol. 2015, 13, 310-317. 
(4) Wan, M.; Chou, C. Class 1 Integrons and the antiseptic resistance gene $(\mathrm{qacE} \Delta 1)$ in municipal and swine slaughterhouse wastewater treatment plants and wastewater associated methicillin-resistant Staphylococcus aureus. Int. J. Environ. Res. Public Health 2015, 12, 6249-6260.

(5) Wozniak, R; Waldor, M. Integrative and conjugative elements: mosaic mobile genetic elements enabling dynamic lateral gene flow. Nat. Rev. Microbiol. 2010, 8, 552-563.

(6) Berglund, B. Environmental dissemination of antibiotic resistance genes and correlation to anthropogenic contamination with antibiotics. Infection Ecology \& Epidemiology 2015, 5.10.3402/iee.v5.28564

(7) Stokes, H.; Holmes, A.; Nield, B.; Holley, M.; Nevalainen, K.; Mabbutt, B.; Gillings, M. Gene cassette PCR: sequence-independent recovery of entire genes from environmental DNA. Appl. Environ. Microbiol. 2001, 67, 5240-5246.

(8) Gillings, M.; Gaze, W.; Pruden, A.; Smalla, K.; Tiedje, J.; Zhu, Y. Using the class 1 integron-integrase gene as a proxy for anthropogenic pollution. ISME J. 2015, 9, 1269-1279.

(9) Cambray, G.; Gerout, A.; Mazel, D. Integrons. Annu. Rev. Genet. 2010, 44, 141-146.

(10) Hardwick, S.; Stokes, H.; Findlay, S.; Taylor, M.; Gillings, M. Quantification of class 1 integron abundance in natural environments using real-time quantitative PCR, 2008; DOI: http://dx.doi.org/10.1111/j. 1574-6968.2007.00992.x.

(11) Wright, M.; Baker-Austin, C.; Lindell, A.; Stepanauskas, R.; Stokes, H.; McArthur, J. Influence of industrial contamination on mobile genetic elements: class 1 integron abundance and gene cassette structure in aquatic bacterial communities. ISME J. 2008, 2, 417-428.

(12) Rosewarne, C.; Pettigrove, V.; Stokes, H.; Parsons, Y. Class 1 integrons in benthic bacterial communities: abundance, association with Tn402-like transposition modules and evidence for co-selection with heavy-metal resistance. FEMS Microbiol. Ecol. 2010, 72, 35-46.

(13) Gaze, W.; Zhang, L.; Abdouslam, N.; Hawkey, P.; Calvo-Bado, L.; Royle, J.; Brown, H.; Davis, S.; Kay, P.; Boxall, A.; Wellington, E. Impacts of anthropogenic activity on the ecology of class 1 integrons and integron-associated genes in the environment. ISME J. 2011, 5, 1253-1261.

(14) Pruden, A.; Arabi, M.; Storteboom, H. Correlation between upstream human activities and riverine antibiotic resistance genes. Environ. Sci. Technol. 2012, 46, 11541-11549.

(15) Jechalke, S.; Schreiter, S.; Wolters, B.; Dealtry, S.; Heuer, H.; Smalla, K. Widespread dissemination of class 1 integron components in soils and related ecosystems as revealed by cultivation-independent analysis. Front. Microbiol. 2014, 4, 420.

(16) Baker-Austin, C.; Wright, M.; Stepanauskas, R.; McArthur, J. Co-selection of antibiotic and metal resistance. Trends Microbiol. 2006, 14, 176-182.

(17) Gillings, M.; Boucher, Y.; Labbate, M.; Holmes, A.; Krishnan, S.; Holley, M.; Stokes, H. The evolution of class 1 integrons and the rise of antibiotic resistance. Journal of bacteriology 2008, 190 (14), 50955100.

(18) Oliveira-Pinto, C.; Costa, P.; Reis, M.; Chartone-Souza, E.; Nascimento, A. Diversity of gene cassettes and the abundance of the class 1 integron-integrase gene in sediment polluted by metals. Extremophiles 2016, 20, 1-7.

(19) Nardelli, M.; Scalzo, P.; Ramírez, M.; Quiroga, M. Cassini M.; Centrón D. Class 1 integrons in environments with different degrees of urbanization. PLoS One 2012, 7, e39223.

(20) Hong, P.; Yannarell, A.; Dai, Q.; Ekizoglu, M.; Mackie, R. Monitoring the perturbation of soil and groundwater microbial communities due to pig production activities. Appl. Environ. Microbiol. 2013, 79, 2620-2629.

(21) Ma, L.; Zhang, X.; Cheng, S.; Zhang, Z.; Shi, P.; Liu, B.; Wu, B.; Zhang, Y. Occurrence abundance and elimination of class 1 integrons in one municipal sewage treatment plant. Ecotoxicology 2011, 20, 968973.

(22) Du, J.; Geng, J.; Ren, H.; Ding, L.; Xu, K.; Zhang, Y. Variation of antibiotic resistance genes in municipal wastewater treatment plant with A2O-MBR system. Environ. Sci. Pollut. Res. 2015, 22, 3715-3726.
(23) Li, J.; Cheng, W.; Xu, L.; Strong, P.; Chen, H. Antibioticresistant genes and antibiotic-resistant bacteria in the effluent of urban residential areas hospitals, and a municipal wastewater treatment plant system. Environ. Sci. Pollut. Res. 2015, 22, 4587-4596.

(24) Makowska, N.; Koczura, R.; Mokracka, J. Class 1 integrase sulfonamide and tetracycline resistance genes in wastewater treatment plant and surface water. Chemosphere 2016, 144, 1665-1673.

(25) Moura, A.; Henriques, I.; Ribeiro, R.; Correia, A. Prevalence and characterization of integrons from bacteria isolated from a slaughterhouse wastewater treatment plant. J. Antimicrob. Chemother. 2007, 60, $1243-1250$

(26) Pellegrini, C.; Celenza, G.; Segatore, B.; Bellio, P.; Setacci, D.; Amicosante, G.; Perilli, M. Occurrence of class 1 and 2 integrons in resistant Enterobacteriaceae collected from a urban wastewater treatment plant. Microb. Drug Resist. 2011, 17 (2), 229-234.

(27) Kaplan, E.; Ofek, M.; Jurkevitch, E.; Cytryn, E. Characterization of fluoroquinolone resistance and qnr diversity in Enterobacteriaceae from municipal biosolids. Front. Microbiol. 2013, 4, 144.

(28) Mokracka, J.; Koczura, R.; Kaznowski, A. Multiresistant Enterobacteriaceae with class 1 and class 2 integrons in a municipal wastewater treatment plant. Water Res. 2012, 46, 3353-3363.

(29) Stalder, T.; Barraud, O.; Jové, T.; Casellas, M.; Gaschet, M.; Dagot, C.; Ploy, M. Quantitative and qualitative impact of hospital effluent on dissemination of the integron pool. ISME J. 2014, 8, 768777.

(30) Tennstedt, T.; Szczepanowski, R.; Braun, S.; PÃhler, A.; SchlÃter, A. Occurrence of integron-associated resistance gene cassettes located on antibiotic resistance plasmids isolated from a wastewater treatment plant. FEMS Microbiol. Ecol. 2003, 45, 239-252.

(31) Zhang, X.; Zhang, T.; Zhang, M.; Fang, H.; Cheng, S. Characterization and quantification of class 1 integrons and associated gene cassettes in sewage treatment plants. Appl. Microbiol. Biotechnol. 2009, 82, 1169-1177.

(32) Pai, H.; Byeon, J.; Yu, S.; Lee, B.; Kim, S. Salmonella enterica serovar typhi strains isolated in Korea containing a multidrug resistance class 1 integron. Antimicrob. Agents Chemother. 2003, 47, 2006-2008.

(33) Michael, G. Class 1 integron-associated gene cassettes in Salmonella enterica subsp. enterica serovar Agona isolated from pig carcasses in Brazil. J. Antimicrob. Chemother. 2005, 55, 776-779.

(34) Gillings, M.; Krishnan, S.; Worden, P.; Hardwick, S. Recovery of diverse genes for class 1 integron-integrases from environmental DNA samples. FEMS Microbiol. Lett. 2008, 287, 56-62.

(35) Huang, L.; Chen, T.; Lu, P.; Tsai, P.; Cho, W.; Chang, F.; Fung, C.; Siu, L. Dissemination of multidrug-resistant class 1 integroncarrying Acinetobacter baumannii isolates in Taiwan. Clin. Microbiol. Infect. 2008, 14, 1010-1019.

(36) Lopes, G.; Michael, G.; Cardoso, M.; Schwarz, S. Identification and characterization of Salmonella enterica subsp. enterica serovar Derby isolates carrying a new aadA26 gene cassette in a class 1 integron obtained at pig slaughterhouses. FEMS Microbiol. Lett. 2014, $356,71-78$.

(37) Caporaso, G.; Lauber, C.; Walters, W.; Berg-Lyons, D.; Huntley, J.; Fierer, N.; Owens, S.; Betley, J.; Fraser, L.; Bauer, M.; Gormley, N. Ultra-high-throughput microbial community analysis on the Illumina HiSeq and MiSeq platforms. ISME J. 2012, 6 (8), 1621-1624.

(38) Leininger, S.; Urich, T.; Schloter, M.; Schwark, L.; Qi, J.; Nicol, G.; Prosser, J.; Schuster, S.; Schleper, C. Archaea predominate among ammonia-oxidizing prokaryotes in soils. Nature 2006, 442 (7104), $806-809$.

(39) Arye, G.; Dror, I.; Berkowitz, B. Fate and transport of carbamazepine in soil aquifer treatment (SAT) infiltration basin soils. Chemosphere 2011, 82, 244-252.

(40) Jacoby, G. $\beta$-Lactamase Nomenclature. Antimicrob. Agents Chemother. 2006, 50, 1123-1129.

(41) Bush, K.; Jacoby, G. Updated functional classification of $\beta$ lactamases. Antimicrob. Agents Chemother. 2010, 54, 969-976. 
(42) Thai, Q.; Bös, F.; Pleiss, J. The Lactamase Engineering Database: a critical survey of TEM sequences in public databases. BMC Genomics 2009, 10, 390.

(43) McArthur, A.; Waglechner, N.; Nizam, F.; Yan, A.; Azad, M.; Baylay, A.; Bhullar, K.; Canova, M.; De Pascale, G.; Ejim, L.; Kalan, L.; King, A.; Koteva, K.; Morar, M.; Mulvey, M.; OBrien, J.; Pawlowski, A.; Piddock, L.; Spanogiannopoulos, P.; Sutherland, A.; Tang, I.; Taylor, P.; Thaker, M.; Wang, W.; Yan, M.; Yu, T.; Wright, G. The Comprehensive Antibiotic Resistance Database. Antimicrob. Agents Chemother. 2013, 57, 3348-3357.

(44) Schloss, P.; Westcott, S.; Ryabin, T.; Hall, J.; Hartmann, M.; Hollister, E.; Lesniewski, R.; Oakley, B.; Parks, D.; Robinson, C.; Sahl, J.; Stres, B.; Thallinger, G.; Van Horn, D.; Weber, C. Introducing mothur: Open-source platform-independent, community-supported software for describing and comparing microbial communities. Appl. Environ. Microbiol. 2009, 75, 7537-7541.

(45) Gish, W.; States, D. Identification of protein coding regions by database similarity search. Nat. Genet. 1993, 3, 266-272.

(46) Buchfink, B.; Xie, C.; Huson, D. Fast and sensitive protein alignment using DIAMOND. Nat. Methods 2014, 12, 59-60.

(47) Maglott, D.; Ostell, J.; Pruitt, K.; Tatusova, T. Entrez Gene: gene-centered information at NCBI. Nucleic Acids Res. 2007, 35, D26D31.

(48) Overbeek, R. The subsystems approach to genome annotation and its use in the project to annotate 1000 genomes. Nucleic Acids Res. 2005, 33, 5691-5702.

(49) Liu, B.; Pop, M. ARDB-Antibiotic Resistance Genes Database. Nucleic Acids Res. 2009, 37, D443-D447.

(50) Kristiansson, E.; Fick, J.; Janzon, A.; Grabic, R.; Rutgersson, C.; Weijdegård, B.; Söderström, H.; Larsson, D. Pyrosequencing of antibiotic-contaminated river sediments reveals high levels of resistance and gene transfer elements. PLoS One 2011, 6, e17038.

(51) Forsberg, K.; Patel, S.; Gibson, M.; Lauber, C.; Knight, R.; Fierer, N.; Dantas, G. Bacterial phylogeny structures soil resistomes across habitats. Nature 2014, 509, 612-616.

(52) Treangen, T.; Koren, S.; Sommer, D.; Liu, B.; Astrovskaya, I.; Ondov, B.; Darling, A.; Phillippy, A.; Pop, M. MetAMOS: a modular and open source metagenomic assembly and analysis pipeline. Genome Biology 2013, 14, R2.

(53) Peng, Y.; Leung, H.; Yiu, S.; Chin, F. Meta-IDBA: a de Novo assembler for metagenomic data. Bioinformatics. Bioinformatics 2011, 27, i94-i101.

(54) Gurevich, A.; Saveliev, V.; Vyahhi, N.; Tesler, G. QUAST: quality assessment tool for genome assemblies. Bioinformatics 2013, 29 (8), 1072-1075.

(55) Moura, A.; Soares, M.; Pereira, C.; Leitão, N.; Henriques, I.; Correia, A. INTEGRALL: a database and search engine for integrons, integrases and gene cassettes. Bioinformatics 2009, 25, 1096-1098.

(56) Koenig, J.; Boucher, Y.; Charlebois, R.; Nesbø, C.; Zhaxybayeva, O.; Bapteste, E.; Spencer, M.; Joss, M.; Stokes, H.; Doolittle, W. Integron-associated gene cassettes in Halifax Harbour: assessment of a mobile gene pool in marine sediments. Environ. Microbiol. 2008, 10, 1024-1038.

(57) Elsaied, H.; Stokes, H.; Kitamura, K.; Kurusu, Y.; Kamagata, Y.; Maruyama, A. Marine integrons containing novel integrase genes attachment sites, attI and associated gene cassettes in polluted sediments from Suez and Tokyo Bays. ISME J. 2011, 5, 1162-1177.

(58) Gillings, M.; Xuejun, D.; Hardwick, S.; Holley, M.; Stokes, H. Gene cassettes encoding resistance to quaternary ammonium compounds: a role in the origin of clinical class 1 integrons? ISME J. 2009, 3, 209-215.

(59) Campbell, E.; Greenwell, R.; Anthony, J.; Wang, S.; Lim, L.; Das, K.; Sofia, H.; Donohue, T.; Darst, S. A conserved structural module regulates transcriptional responses to diverse stress signals in bacteria. Mol. Cell 2007, 27 (5), 793-805.

(60) Koenig, J.; Bourne, D.; Curtis, B.; Dlutek, M.; Stokes, H.; Doolittle, W.; Boucher, Y. Coral-mucus-associated Vibrio integrons in the Great Barrier Reef: genomic hotspots for environmental adaptation. ISME J. 2011, 5, 962-972.
(61) Holmes, A.; Gillings, M.; Nield, B.; Mabbutt, B.; Nevalainen, B.; Stokes, $\mathrm{H}$. The gene cassette metagenome is a basic resource for bacterial genome evolution. Environ. Microbiol. 2003, 5, 383-394.

(62) Korzeniewska, E.; Harnisz, M. Extended-spectrum betalactamase (ESBL)-positive Enterobacteriaceae in municipal sewage and their emission to the environment. J. Environ. Manage. 2013, 128, 904-911.

(63) Amador, P.; Fernandes, R.; Prudêncio, M.; Barreto, M.; Duarte, I. Antibiotic resistance in wastewater: Occurrence and fate of Enterobacteriaceae producers of Class A and Class C $\beta$-lactamases. J. Environ. Sci. Health, Part A: Toxic/Hazard. Subst. Environ. Eng. 2015, 50, 26-39.

(64) Laht, M.; Karkman, A.; Voolaid, V.; Ritz, C.; Tenson, T.; Virta, M.; Kisand, V. Abundances of tetracycline sulphonamide and betalactam antibiotic resistance genes in conventional wastewater treatment plants (WWTPs) with different waste load. PLoS One 2014, 9, e103705.

(65) Guo, X.; Xia, R.; Han, N.; Xu, H. Genetic diversity analyses of class 1 integrons and their associated antimicrobial resistance genes in Enterobacteriaceae strains recovered from aquatic habitats in China. Lett. Appl. Microbiol. 2011, 52, 667-675.

(66) Moura, A.; Oliveira, C.; Henriques, I.; Smalla, K.; Correia, A. Broad diversity of conjugative plasmids in integron-carrying bacteria from wastewater environments. FEMS Microbiol. Lett. 2012, 330, 157164.

(67) Mobashery, S.; Cha, J.; Kotra, L. Resistance to beta-lactam antibiotics mediated by beta-lactamases: structure, mechanism and evolution. In Bacterial Resistance to Antimicrobials; Wax, R., Taber, H.; Salyers, A., Kim, L., Eds.; CRC Press, 2007, 103-132.

(68) Naas, T.; Poirel, L.; Nordmann, P. Minor extended-spectrum $\beta$ lactamases. Clin. Microbiol. Infect. 2008, 14, 42-52.

(69) Dubois, V.; Poirel, L.; Marie, C.; Arpin, C.; Nordmann, P.; Quentin, C. Molecular Characterization of a Novel Class 1 Integron Containing blaGES-1 and a Fused Product of aac(3)-Ib/aac(6)-Ib Gene Cassettes in Pseudomonas aeruginosa. Antimicrob. Agents Chemother. 2002, 46, 638-645.

(70) Wachino, J.; Doi, Y.; Yamane, K.; Shibata, N.; Yagi, T.; Kubota, T.; Ito, H.; Arakawa, Y. Nosocomial spread of ceftazidime-resistant Klebsiella pneumoniae strains producing a novel class A $\beta$-Lactamase GES-3, in a neonatal intensive care unit in Japan. Antimicrob. Agents Chemother. 2004, 48, 1960-1967.

(71) Jeong, S.; Bae, I.; Kim, D.; Hong, S.; Song, J.; Lee, J.; Lee, S. First outbreak of Klebsiella pneumoniae clinical isolates producing GES5 and SHV-12 extended-spectrum $\beta$-lactamases in Korea. Antimicrob. Agents Chemother. 2005, 49, 4809-4810.

(72) Walther-Rasmussen, J.; Hoiby, N. Class A carbapenemases. J. Antimicrob. Chemother. 2007, 60, 470-482.

(73) Labuschagne, C.; Weldhagen, G.; Ehlers, M.; Dove, M. Emergence of class 1 integron-associated GES-5 and GES-5-like extended-spectrum $\beta$-lactamases in clinical isolates of Pseudomonas aeruginosa in South Africa. Int. J. Antimicrob. Agents 2008, 31, 527530.

(74) Girlich, D.; Poirel, L.; Szczepanowski, R.; Schluter, A.; Nordmann, P. Carbapenem-hydrolyzing GES-5-encoding gene on different plasmid types recovered from a bacterial community in a sewage treatment plant. Appl. Environ. Microbiol. 2012, 78, 12921295.

(75) Manageiro, V.; Ferreira, E.; Canica, M.; Manaia, C. GES-5 among the $\beta$-lactamases detected in ubiquitous bacteria isolated from aquatic environment samples. FEMS Microbiol. Lett. 2014, 351, 64-69.

(76) Tansirichaiya, S.; Rahman, M.; Antepowicz, A.; Mullany, P.; Roberts, A. Detection of novel integrons in the metagenome of human saliva. PLoS One 2016, 11 (6), e0157605.

(77) Wang, J.; Stephan, R.; Zurfluh, K.; HÃchler, H.; Fanning, S. Characterization of the genetic environment of blaESBL genes integrons and toxin-antitoxin systems identified on large transferrable plasmids in multi-drug resistant Escherichia coli. Front. Microbiol. 2015, $5,716$. 
(78) Iqbal, N.; Guérout, A.; Krin, E.; Le Roux, F.; Mazel, D. Comprehensive functional analysis of the 18 Vibrio cholerae N16961 toxin-antitoxin systems substantiates their role in stabilizing the superintegron. J. Bacteriol. 2015, 197, 2150-2159.

(79) Blatch, G.; Lässle, M. The tetratricopeptide repeat: a structural motif mediating protein-protein interactions. BioEssays 1999, 21 (11), 932-939.

(80) van Elsas, J.; Chiurazzi, M.; Mallon, C.; Elhottova, D.; Kristufek, V.; Salles, J. Microbial diversity determines the invasion of soil by a bacterial pathogen. Proc. Natl. Acad. Sci. U. S. A. 2012, 109, 11591164.

(81) Gatica, J.; Yang, K.; Pagaling, E.; Jurkevitch, E.; Yan, T.; Cytryn, E. Resistance of undisturbed soil microbiomes to ceftriaxone indicates extended spectrum $\beta$-lactamase activity. Front. Microbiol. 2015, 6, 1233.

(82) Da Silva, M.; Vaz-Moreira, I.; Gonzalez-Pajuelo, M.; Nunes, O.; Manaia, C. Antimicrobial resistance patterns in Enterobacteriaceae isolated from an urban wastewater treatment plant. FEMS Microbiol. Ecol. 2007, 60, 166-176.

(83) Stalder, T.; Barraud, O.; Casellas, M.; Dagot, C.; Ploy, M. Integron involvement in environmental spread of antibiotic resistance. Front. Microbiol. 2012, 3, 119.

(84) Negreanu, Y.; Pasternak, Z.; Jurkevitch, E.; Cytryn, E. Impact of treated wastewater irrigation on antibiotic resistance in agricultural soils. Environ. Sci. Technol. 2012, 46, 4800-4808. 